\title{
Does Organizational Culture Impact on Firm Performance: Evidence From Turkey*
}

\author{
Adem Boyukaslan1 ๑, Hasan Rıza Așıkoğlu2 $\odot$
}

\begin{abstract}
This paper aims to examine the impact of corporate culture over the financial performance of certain enterprises therewith by covering the data of chemical, petroleum, rubber and plastic products firms (XCHEMST) traded in Borsa Istanbul. In that regard, corporate culture data have been obtained from the surveys of the Denison's Organizational Culture Model (DOCM) employees and managers of these businesses while the financial data were gleaned from financial statements of the mentioned enterprises between 2012-2016. We posited the ROE as a dependent variable while ROA and DEBT EQUITY have been employed as explanatory financial variables. Accordingly, we have determined SIZE and AGE as firm-specific variables. Utilizing cross-sectional data and multiple linear regression models, we estimated the coefficients of the variables with the aid of an OLS estimator. In so doing, this paper provides sufficient empirical evidence that three out of four cultural traits in the Denison's Theory have had no impact on the financial performance of Turkey's chemical firms traded on BIST, whereas the mission trait has had a significant impact. Consequently, our results are largely in line with the findings of other $\mathrm{C} / \mathrm{P}$ research, suggesting that the mission trait of the DOCM is the core cultural term in ensuring thriving firm corporate performance.
\end{abstract}

\section{Keywords}

Firm Performance, Effectiveness, Organizational Culture, Organizational Behaviour, Emerging Market Countries

\section{Introduction}

In past decades, researchers have broadly focused on characterizing, conceptualizing and measuring (to build a model) culture phenomenon and other aspects of organizational culture. For example, Hartnell, Ou \& Kinicki (2011) have remarked that over 4600 manuscripts have revealed the isomorphic structure of organizational culture and the impetus behind the social characteristics that influence employee behavior, subsuming the idea that it is the people who make up the culture. Although Lewin (1951) had earlier noticed that a number of forces pushing or attracting each other constitute a special movement within enterprises, it had not

\footnotetext{
* This work is based on the first author's doctoral dissertation. He would like to deliver his sincere gratitude to committee members for their supports and invaluable contributions. The author also would like to present his special thanks to the Scientific Research Projects Commission of Afyon Kocatepe University for funding the research data.

1 Corresponding Author: Adem Boyukaslan (Dr.), Afyon Kocatepe University, Faculty of Economics and Administrative Sciences, International Trade and Finance Dept., Afyon, Turkey. E-mail: ademboyukaslan@aku.edu.tr, ORCID ID: 0000-0002-9073-0554

2 Hasan Rıza Aşıkoğlu (Prof. Dr.), Afyon Kocatepe University, Faculty of Economics and Administrative Sciences, International Trade and Finance Dept., Afyon, Turkey. E-Mail: riza@aku.edu.tr, ORCID ID: XX

To cite this article: Boyukaslan, A., \& Asikoglu, H. R. (2022). Does Organizational Culture Impact on Firm Performance: Evidence From Turkey. Istanbul Business Research. Advanced Online Publication. http://doi.org/10.26650/ibr.2022.51.861397
} 
aroused research interest in the impact of this organizational phenomenon on firms' outcomes until the 1980's. In other respects, in recognizing the uniqueness of culture and the distinctive characteristics of the organizations, some academics and business practitioners have turned their eyes to this difference-maker and inimitable strategic resource (Hofstede \& Peterson, 2000). For instance, in a landmark C/P study, Kotter \& Heskett (1992) claimed that organizational culture is a way of managing, and firms may boost their effectiveness and outcomes by embracing the culture as a management philosophy. Additionally, their contemporary colleague, Schein (1992), pointed out that maximizing the value of human resources is vital because intellectual assets constitute the primary resources for creating value in firms; and it is essential for corporations to have a culture imbued with intellectual attendance (Olughor, 2014). In the sequel, Y1lmaz \& Ergun (2008) highlighted another dimension on the value of determining the cultural predictors of organizational effectiveness, discriminating highly productive firms from less productive ones and the drivers of organizational change.

A long-standing research stream on $\mathrm{C} / \mathrm{P}$ studies has brought about immense enrichment to the field and the results/methods in these studies have led to a remarkable compilation guide for further inquiries. Our work, as a nominee, has taken some important points into account by taking advantage of the accumulated richness of the past. Before proceeding to the next section, we will underline some of the prominent considerations emerging from previous studies that reveal the blind-alley nature of the $\mathrm{C} / \mathrm{P}$ link due elements exclusively determinant to the methodology of our study. Note that the aforementioned considerations have forced the present research to adopt certain assumptions in order to extricate the impact of the corporate culture on financial performance. We specifically present empirical evidence with the following conditions.

The first concerns how organizational culture changes in the course of time and the temporal impact of culture related to outcomes over time. Some analysts, for instance Kotter \& Heskett (1992), stated that crises and new challenges force inherent cultural values to change the way things are done in an organization and the set of practices that are widely shared within a business culture. In fact, they can prevail over the organization in the long run. It can reliably be presumed that culture is relatively stable over time (Bezrukova et al., 2012) and it is difficult to change (Davidson et al., 2007). In regard to the culture and time linkage, many researchers suggest that the magnitude of $\mathrm{C} / \mathrm{P}$ connections remains stable or increases slightly within a one-to-six year period following cultural assessment (Gordon \& Di Tomaso, 1992; Denison \& Mishra, 1995; Boyce et al., 2015). Within the scope of available information, our study acknowledges that measuring organizational culture at one time is sufficient to represent it and other cultural traits as variables within the analysis because of the fact that culture can be dominant and stable for many years due to the beliefs and deep assumptions engrained.

A second acknowledgement is related to the contingent effect of the external environment and industry type on the $\mathrm{C} / \mathrm{P}$ interplay. As several authors have pointed out in prior works, it is 
possible that the industry type may have a disparate relationship with culture traits (Denison \& Mishra, 1995) and business outcomes (Glaser, 2014); accordingly, the nature of the business environment may further affect the financial results of the firms through various competitive conditions (Zheng et al., 2009). Our study takes industry effects into consideration, and we have chosen one industry type: chemicals, petroleum, rubber and plastic products in order to limit the impact of different sectors on both culture and outcomes.

The third revolves around the most unbridgeable point in $\mathrm{C} / \mathrm{P}$ studies as per our opinion and it needs to be clearly explained. The question of where organizational movement fits among the factors that have an impact on financial statements has not yet been answered even though remarkable effort has been oriented toward corporate culture as an important feature of organizations (Petty et al., 1995). However, some researchers, such as Denison \& Mishra (1995), have claimed that culture influences a wide variety of performance indicants, while some assert that each cultural trait relates to specific performance measures in its own unique way (Hartnell et al. 2011). It is obvious that results remain ambiguous and the impact of culture on financial statements has not been fully illuminated. A default effect may not be evident on financial performance indicators because culture is not included in financial statements. For instance, culture may have a clear impact on the balance sheet when providing external financing or increasing the firm's assets through an investment. But how can the contribution of the culture to performance be distinctly monitored by financial indicators derived from financial tables? To find out, we underline the fact that financial statements may be further influenced by the various financing and investment decisions of firms. So, we tried to devise a model where the indicators obtained from the financial statements generate consistent results. Afterwards, we tested our corporate culture variables together with the proposed model to obtain our main findings and expose the clear impact of corporate culture on financial indicators.

A fourth concern is the causality and timing issue in $\mathrm{C} / \mathrm{P}$ connection. It partially relates to previous assumptions. It is quite possible to emphasize that different approaches have recently been introduced to the research field to reveal the blind-alley nature of the $\mathrm{C} / \mathrm{P}$ linkage. As a noteworthy example of giving a point to causal priority's crucial importance, Boyce et al. (2015) claimed that previous works have been generally inadequate in establishing any causality. They did not indicate any direction for $\mathrm{C} / \mathrm{P}$ linkage although they have been supporting an association between culture and business outcomes. The causality issue involves the change of culture over time, but it is unclear at what time the effect of culture contributes to financial outcomes due to the temporal delay in the intricate nature of $\mathrm{C} / \mathrm{P}$ research. Herewith, the contribution of the culture does not become apparent in addition to other organizational strategies and managerial instruments that contribute to the return on investment for various performance outcomes over time (Boyce et al. 2015). While the causality effect has been decisive for our research design, our basic approach encompasses unilateral causality from culture to performance outcomes, as concluded by Boyce et al. (2015). 
The purpose of the present study is to investigate and discuss the impact of an organizational culture on its financial performances (abbreviated as $\mathrm{C} / \mathrm{P}$ from now on) from the perspective of Turkey, as an ambassador of an emerging economy context, instead of the western/ overseas countries that host most of the studies in the literature. To this end, our study is based on Denison's Theory of organizational culture and firm performance. Hence, it presents empirical evidence from an industry of which companies operate in a volatile economy. Such fast-changing conditions may probably impel firms to a versatile business environment and force them to shoulder much more financial risk. Accordingly, the present study attempts to add a set of financial variables in order to build a concrete regression model and narrow the gap in elucidating the full impact of culture on performance.

Beginning with the introduction, the structure of the paper is as follows: the next section offers a justification of Denison's Organizational Culture Theory in relation to organizational outputs. We, then, proceed to the study's hypotheses. The subsequent one encloses the methodology with three sub-sections: data collection and sample characteristics, the presentation of the variables and the validation of the scale and preliminary analyses. Finally, the findings of the study are presented in the follow-up section while the results of our analysis are discussed in a final section.

\section{Denison's Theory and Firm Performance}

As for the framework of the organizational culture in relation to firm effectiveness, based on empirical research, case studies and new cutting-edge theoretical models on organizational behavior, Denison (1990) has developed a framework that offers a new approach with four ideas about producing a productive work environment. In the following years, Denison and his colleagues (Denison \& Mishra, 1995; Denison \& Neale, 1996, 1999; Fey \& Denison, 2003, Denison et al., 2003a; 2003b) advanced the theory with cross-cultural relevance by measuring and comparing the cultural characteristics of organizations in different national settings, resulting in empirical results on the performance of enterprises performing in various national contexts.

Denison's Organizational Culture Model with Main Axes and Organizational Direction

\begin{tabular}{lc|c}
\hline \hline Compliance with & Change and Flexibility & Consistency and Direction \\
\cline { 2 - 3 } External Conditions & Adaptability & Mission \\
\hline Integration within the & Involvement & Consistency \\
\cline { 2 - 3 } Organization & & \\
\hline \hline
\end{tabular}

Source: Denison and Mishra, 1995. 
Denison's survey has been tested in many national contexts around the world such as Canada, Australia, Brazil, the U.S., Japan, Jamaica, South Africa (Denison et al. 2003a; 2003b), Russia and the U.S. (Fey \& Denison, 2003). The aforesaid studies have been finalized as comparative field studies and the first revelation of a level of similarity across the region. In a dual country crosscheck, they produced results in the opposite direction. Accordingly, cultural traits and effectiveness indicators might vary from one country to another. For instance, the adaptability trait has been the most effective driver of performance in Russian firms, the mission focus emerged as the strongest trait in the U.S. (Fey \& Denison, 2003). Earlier studies by Denison produced different results on which cultural traits have been influential on effectiveness indicators (Denison \& Mishra, 1989; 1995); but in support of his theory, mostly positive correlations between these traits and a range of effectiveness criteria have been reported in a variety of organizational, sectoral and national contexts.

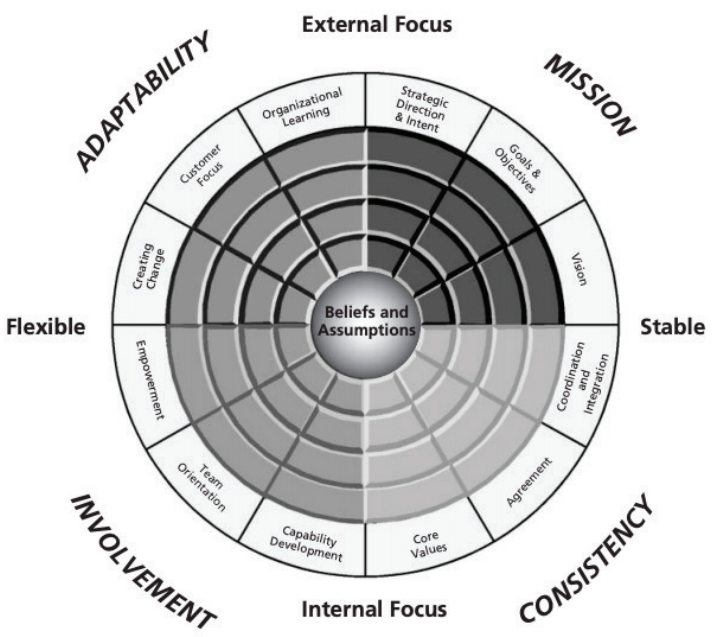

Figure 1. The Denison Organizational Culture Model with Cultural Dimensions and Traits Source: Denison and Neale, 1996.

As shown in Figure-1, the model theoretically manifests a set of traits and auxiliary subcomponents in order to accurately discern which cultural dimension (or trait) enables or restricts organizational effectiveness and change (Y1lmaz \& Ergun, 2008). In this way, it serves as a holistic evaluation of organizational culture with; (1) organizational performance, (2) organizational development and (3) other internal and external organizational capabilities that reveal the relationship mainly between organizational culture, efficiency and change.

Denison's Model contains underlying beliefs and assumptions at the core, similar to Schein's (1984) organizational culture model. Structurally, the model principally consists of two main axes: internal focus and external focus. In addition, the model subsumes four major cultural traits: involvement, consistency, adaptability and mission. It also suggests that 
effective firms possess all four cultural traits. Accordingly, organizational effectiveness is characterized by the balancing and simultaneous pursuit of the competing demands for which these values stand. In this direction, Denison et al., (2014) further concluded that the most effective organizations have high levels of each trait or a full profile of them.

\section{Research Hypothesis}

The theoretical and informational background of this study suggests two empirically testable statements: (1) the organizational culture, estimated as the sum of the scores of four broad cultural traits, has a significant impact on the indicator of firm profitability and (2) each of four traits (a) involvement, (b) consistency, (c) adaptability, (d) mission separately has a significant effect on the indicant of firm profitability (as the effects of other cultural traits are controlled for). Pursuant to the first statement, it subsumes four broad traits and tests their combined power whereas the latter statement refers to the cultural trait's singular power on the performance indicator. Hence, we first tested a logical and reasonable main hypothesis derived from Denison's Theory and the empirical findings of previous studies in following fashion:

Hypothesis 1: As a cumulative score of four cultural traits, there is a relationship between organizational culture and the return on equity.

Referring to the function of building employee capability, contribution and responsibility, the involvement trait helps organizations create multiple decision mechanisms by incorporating different and new ideas into the decision-making processes, allowing employees to care about the organization with a sense of ownership and commitment and enabling the actuation of team dynamics to solve complicated problems. In accordance with these facilities, as Denison \& Neale (1996) states, it procures the internal integration of firms besides flexibility and creativity. Based on the information provided, the following hypothesis is suggested;

Hypothesis 2: Involvement dimension of organizational culture has a positive effect on the return on equity indicator.

The consistency trait briefly covers whether the organization is well-structured and owns a strong and coordinated internal culture intensely felt by the members. Reducing the requirements for certain control systems (probably external sources and related costs) by facilitating connection and communication (Fisher, 1997) it also refers to improving organizational efficiency and effectiveness, two components of firm performance. Based on these arguments, the following hypothesis is developed;

Hypothesis 3: Consistency dimension of organizational culture has a positive effect on the return on equity indicator. 
Adaptability symbolizes the degree to which a firm is able to fit rapidly into the changes and demands of the business environment; for instance, signals from customers, suppliers and the marketplace (Olughor, 2014). It further facilitates the transformation of external signals into internal changes to enhance a firm's skills to overcome the increasing dynamism and volatility of its business environment, while it assumes a certain predictor of a firm's capability to gain new territories (Y1lmaz \& Ergun, 2008). Based on the information given, the following hypothesis is suggested:

Hypothesis 4: Adaptability dimension of organizational culture has a positive effect on the return on equity indicator.

Based on presumed organizational meaning and purpose, the mission trait refers to the existence of a shared definition of the function and purpose of the organization and its members. The trait is accordingly beneficial in troubleshooting if the firm is in danger of shortsightedness or is equipped with a systematically-defined strategic and action plan (Olughor, 2014). It also places emphasis on the stability of the organizational structure and assumes it is the strongest driver of market share, financial performance indicators and overall firm performance (Y1lmaz \& Ergun, 2008). Based on the information provided above, the final hypothesis of the paper is suggested:

Hypothesis 5: Mission dimension of organizational culture has a positive effect on the return on equity indicator.

\section{Methodology}

As organizational culture data was compiled at a single point in time, it has been decisively determinant on the preference for cross-sectional data in the analysis. In this context, we measured employee perceptions in varied departments of selected firms in order to form organizational culture variables.

We formed the corporate culture variables using cross-sectional data and made co-efficient estimations of these variables with the Ordinary Least Square (OLS) estimator for the Multiple Linear Regression Model. Subsequently, we run the Ramsey Regression Specification Error Test (Ramsey's Reset) to detect functional model building errors that may have occurred due to the lack of a proper relationship between the dependent and observed variables. In additon the Omitted Variable Bias Test (OVB) performed to determine any measurement errors that might have occured if some variables were wrongly excluded from the regression model. To tackle the frequently-encountered heteroscedasticity problems in the regression models, we used Eicker (1967), Huber (1967) and White's (1980) t-statistic values that are resistant to standard errors and not affected by the heteroscedasticity issue. 
The study's econometric model entailed a two-step analysis. The first step was to constitute a model that produced stable statistical results before appending the cultural traits. The second was to reveal the hypothetical impact of culture on performance with the addition of cultural variables. From this perspective, we first attempted to establish a fundamental regression equation with a higher internal stability in order to accurately figure out the supposed impact of corporate culture on financial performance. The logarithmic expression of the basic regression equation (1) in the study is as follows;

$$
\mathrm{ROE}_{\mathrm{it}}=\mathrm{a}_{\mathrm{it}}+\beta_{1} \mathrm{ROA}_{\mathrm{it}}+\beta_{2} \mathrm{DEBTEQTY}_{\mathrm{it}}+\beta_{3} \mathrm{SIZE}_{\mathrm{it}}+\beta_{4} \mathrm{SIZE}^{2} \mathrm{it}+\beta_{5} \mathrm{AGE}_{\mathrm{it}}+\mathrm{u}_{\mathrm{it}}
$$

In equation (1), $R O E$ refers to return on equity, $R O A$ stands for return on asset, $D E B$ $T E Q T Y$ is the debt to equity ratio, SIZE denotes firm size, $A G E$ stands for firm age, the subscript $t$ denotes a single point in time, $\beta$ stands for the parameters that are coefficients to be estimated, $a$ is the drift term and $u_{\mathrm{t}}$ is the error term.

Following the substantial equation (1), we tested the impact of culture on business performance by positing corporate culture variables and interaction terms for the basic model and formed equations (2), (3), (4), (5) and (6).

Addition to equation (1), it can be expressed with organizational culture variables in logarithmic forms in the following fashion;

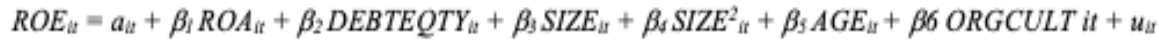

$$
\begin{aligned}
& R O E_{i t}=a_{i t}+\beta_{t} R O A_{i t}+\beta_{2} D E B T E Q T Y_{i t}+\beta_{3} S I Z E_{i t}+\beta_{4} S I Z E^{2}{ }_{i t}+\beta_{5} A G E_{i t}+\beta 6 I N V i t+u_{i t}
\end{aligned}
$$

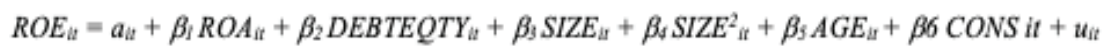

$$
\begin{aligned}
& R O E_{i t}=a_{i t}+\beta_{l} R O A_{i t}+\beta_{2} D E B T E Q T Y_{i t}+\beta_{3} S I Z E_{i t}+\beta_{4} S I Z E^{2}{ }_{i t}+\beta_{5} A G E_{i t}+\beta 6 A D A P T i t+u_{i t}
\end{aligned}
$$

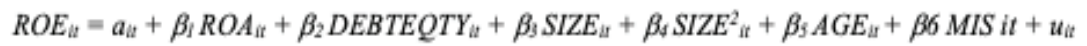

In equation (2) ORGCULT denotes organizational culture as a composite expression of four cultural dimensions. In equation (3) $I N V$ stands for the involvement trait of culture, in equation (4) CONS stands for consistency trait of culture, in equation (5) ADAPT refers to the adaptability trait of culture and finally in equation (6) MIS denotes mission trait of culture in Denison's Organizational Culture Theory.

Due to the fact that the age of the enterprise is not distributed homogeneously for all, it is considered that organizational culture scores of relatively small enterprises may be misleading. Similarly, the independent variables, considered as linear relationships, may have a possible effect on the power and direction of the model. It is recommended to use interaction terms in the literature to control this effect (Karaca-Mandic et al., 2012). Using interaction terms, a new variable was created by multiplying the variables that did not show a statistical 
significance on the dependent variable alone. In this context, we used five interaction terms derived from the multiplication of organizational culture traits with the firm age and enriched the equivalent model with an algebraic multiplication.

\section{Data Collection and Sample Characteristics}

The sample of the study included chemical, petroleum, rubber and plastic products (XCHEMST) enterprises in Borsa Istanbul (BIST) sectoral classifications. The companies in BIST are obliged to publish their quarterly/annual financial reports through the Public Disclosure Platform. The reason for choosing XCHEMST firms in the study is that these enterprises have the highest number of BIST sectoral classifications.

The XCHEMST index is constituted of small and medium-sized enterprises that provide input as to the products needed by the manufacturing industry such as agriculture, automotive, construction, food, health, apparel and cosmetics. It has additional critical petrochemical refineries and large-scale enterprises that produce and distribute natural gas. Thus, the sample of the study consists of enterprises on different scales. When selecting the sample, we paid special attention to the sector exposed to the same environmental competition conditions and considered its impact on organizational culture. Thus, we aimed to limit the changing effects of sectoral differences on culture. The data of the two enterprises were excluded from the analysis due to outlier values.

The financial data of the study were rigorously transcribed from the financial statements of XCHEMST firms. This financial data was based on five consecutive years' (the period 2012-2016) while financial ratios were averaged from the BIST Data Store and PDP's (Public Disclosure Platform of BIST) official website.

Adhering to Denison and Mishra (1995) original instrument with 60 items, Yahyagil (2004) proposed a survey by testing its validity and reliability in Turkey with a total of 36 items using a Likert-type scale with five response options ranging from strongly disagree $(=1)$ to strongly agree $(=5)$. We followed Yahyagil's advice and arranged two items in reverse form to prevent reflexive responses from informants. Then we converted the data into the normal form and included it in the data set. Afterwards, the questionnaires were directed to the informants to evaluate the corporations' organizational cultures. Finally 322 informants voluntarily participated in the study from different units and having various hierarchical titles, consisting mainly of white-collar high-level managers, unit managers and experts from whom became the team leaders, technical staff and blue-collar workers.

In addition to the financial and culture data, we also employed firm-specific variables-firm age and firm size- in the analysis. The number of employees was obtained through PDP 
notifications, company web pages and press releases, while firm age information came from company webpages. The average number of employees in the participating enterprises was 852 (S.D.=1436) and all of the XCHEMST sector enterprises with consistent data are represented in the analyses. The participants included in the research had a balanced distribution although their numbers vary slightly. When the age and size were evaluated, it was highlighted that 17 of the XCHEMST enterprises have between $1-250$ employees ( $51 \%$ of the total) and 25 are between $31-86$ years of age ( $75 \%$ of the total).

As to the characteristics of the respondents, $60 \%$ are male and $40 \%$ are female, while a total of $81 \%$ have university and higher level graduate degrees. Of the 322 respondents, 65 are aged between 20 and 30 years, 131 are $31-40$ years, 100 are $41-50$ and 25 are 51 or older. The majority of the participants are between the ages of 31-50 and may be considered to have sufficient work tenure. In addition, 228 of the participants (70.8\%) stated that they have been working in the same workplace for more than four years. Considering their age, education, position and working hours, it can be stated that all participants were aware of cultural characteristics such as participative processes, authorization, change creation, customer focus, business vision-mission, management philosophy, and capability development.

\section{Variables}

Dependent Variables: The return on equity (ROE) ratio is considered to be the most important bottom-line financial indicator of the ultimate profitability and earnings per share capital of the shareholders in business research. It also reflects the effective use of the capital provided by the shareholders and the effect of financial leverage on the firm's profitability (Cakir \& Kucukkaplan, 2012). Hence, the return on equity ratio was chosen as the dependent variable of the study.

Explanatory Financial Variables: We used two different financial variables to ensure the internal consistency of the regression model and to make the effects of the other variables in the model more visible on the dependent variable. One of these variables is the return on assets $(R O A)$ ratio that expresses the extent to which business assets are exploited to generate income (Ongore \& Kusa, 2013) while the other is the total debt to equity (DEBTEQTY) ratio, a strong indicator of the capital structure.

Firm-Specific Variables: According to Yılmaz \& Ergun (2008), business-specific indicators are greatly influenced by factors such as firm size and sector type. We therefore employed firm size (SIZE) and firm age $(A G E)$ as control variables in our estimations by taking into account the possible effects of the same firm-specific factors on business profitability.

As to the firm-specific factors, past work shows that there is no permanent relationship between firm size and profitability in the same direction (John \& Adebayo, 2013). It has also 
been observed in these studies that firm size was constituted picking different financial indicators such as total assets (Makori \& Jagongo, 2013), total sales (Horvath \& Spirollari, 2012), total equity (Koerniadi \& Tourani-Rad, 2012) and number of employees (Fey \& Denison, 2000). But the data, derived from financial statements such as assets, sales or equity are generally considered as indicators of business performance in the finance literature. Surely, when generated by financial statements, the firm age variable likely will give different results than those generated by the number of employees. In our opinion, the firm size variable is rather fair in comparison to the number of employees. Claiming that the number of employees is more significant than any financial indicant as firm size, Kaen \& Baumann (2013) argue that there is a positive relationship between firm size and profitability, but they also suggest that this is not an ever-increasing effect and the size of the firm has a diminishing effect on total profitability as the firm scale grows. While attaching importance to the suggestions of Kaen \& Baumann (2013), we took into consideration an inverted-U type relationship between firm size \& profitability and finally attached the $S I Z E^{2}$ variable to the equations.

Organizational Culture Variables: Measurement instruments belonging to organizational culture traits were derived from the reputed Denison's Organizational Culture Survey. Adopting the questionnaire items, our cultural variables were ORGCULT, INV, CONS, ADAP, MIS as representing traits.

Table 1

Categorical Classification, Ratio Types and Formulae and Expected Coefficient Signs of the Variable

\begin{tabular}{lllc}
\hline Variable Code & Variable Definition & Calculation & Exp. Sign of Coef. \\
\hline ROE & Return On Equity & Net Profit/ Total Equity & + \\
\hline ROA & Return On Asset & Net Profit / Total Assets & + \\
\hline DEBTEQTY & Debt To Equity Ratio & Total Liabilities / Total Equity & + \\
\hline SIZE & Firm Size & Number of Employees & $+/-$ \\
\hline AGE & Firm Age & Current Year - Firm's Foundation Year & $+/-$ \\
\hline ORGCULT & Organisational Culture & $\begin{array}{l}\text { Involvement + Consistency + Adaptability + Mission } \\
\text { Traits* }\end{array}$ & + \\
\hline INV & Involvement Trait of DOCM* & Score of the Involvement Trait & + \\
\hline CONS & Consistency Trait of DOCM & Score of the Consistency Trait & + \\
\hline ADAP & Adaptability Trait of DOCM & Score of the Adaptability Trait & + \\
\hline MIS & Mission Trait of DOCM & Score of the MissionTrait & + \\
\hline INTTERM1 & Interaction Term 1 & Organisational Culture Score x Firm Age & + \\
\hline INTTERM2 & Interaction Term 2 & Involvement Trait Score x Firm Age & + \\
\hline INTTERM3 & Interaction Term 3 & Consistency Trait Score x Firm Age & + \\
\hline INTTERM4 & Interaction Term 4 & Adaptability Trait Score x Firm Age & + \\
\hline INTTERM5 & Interaction Term 5 & Mission Trait Score x Firm Age & + \\
\hline
\end{tabular}

Notes: *DOCM= Denison's Organizational Culture Model **Variables are formed with arithmetic mean values of four cultural traits.

Table 1 displays the codes of the variables in the regression models, indicating how they were formed, the categorical group they belong to and the expected coefficient signs in the estimation of the parameters. 


\section{Instrument Validation and Preliminary Analysis}

We performed a Confirmatory Factor Analysis (CFA) to assess the validity and reliability of the psychometric properties for the entire scale, the cultural traits and each component characteristic at the item level. The results of the CFA are depicted in Table 2.

Table 2

Descriptive Statistics for Reliability Coefficients of the DOCM, Cultural Traits and Components

\begin{tabular}{|c|c|c|c|c|c|}
\hline Trait & Sub-Components & $\underset{\text { Coefficient }}{\alpha}$ & Sub-Components & $\underset{\text { Coefficient }}{\alpha}$ & Trait \\
\hline \multirow{9}{*}{ 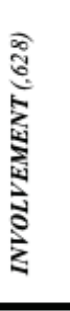 } & Empowerment (Item 1) & ,788 & Core Values (Item 10) & ,788 & \multirow{9}{*}{ 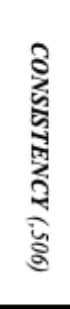 } \\
\hline & Empowerment (Item 2) &, 789 & Core Values (Item 11) & ,791 & \\
\hline & Empowerment (Item 3) & ,788 & Core Values (Item 12) &, 787 & \\
\hline & Team Orientation (Item 4) & ,786 & Agreement (Item 13) &, 787 & \\
\hline & Team Orientation (Item 5) & .788 & Agreement (Item 14) & .787 & \\
\hline & Team Orientation (Item 6) & ,788 & Agreement (Item 15) &, 793 & \\
\hline & Capability Dev. (Item 7) &, 787 & Coord.and Integrt. (Item 16) &, 790 & \\
\hline & Capability Dev. (Item 8) &, 787 & Coord.and Integrt. (Item 17) & ,789 & \\
\hline & Capability Dev. (Item 9) & ,788 & Coord.and Integrt. (Item 18) & 806 & \\
\hline \multirow{9}{*}{ 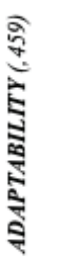 } & Creating Change (Item 19) & ,790 & Str.Dir.and Intent (Item 28) &, 788 & \multirow{9}{*}{ 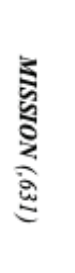 } \\
\hline & Creating Change (Item 20) & ,788 & Str.Dir.and Intent (Item 29) & ,790 & \\
\hline & Creating Change (Item 21) &, 803 & Str.Dir.and Intent (Item 30) & ,792 & \\
\hline & Customer Focus (Item 22) & ,789 & Goals and Object. (Item 31) & 790 & \\
\hline & Customer Focus (Item 23) & ,788 & Goals and Object. (Item 32) & ,786 & \\
\hline & Customer Focus (Item 24) & ,786 & Goals and Object. (Item 33) &, 785 & \\
\hline & Org. Learning (Item 25) & 790 & Vision (Item 34) & ,784 & \\
\hline & Org. Learning (Item 26) &, 789 & Vision (Item 35) &, 786 & \\
\hline & Org. Learning (Item 27) & ,786 & Vision (Item 36) &, 787 & \\
\hline
\end{tabular}

Notes: Reliability Coefficient of the Model (Cronbach's Alpha) $\alpha=, 794$ Total Item $=36$

Showing the lower estimate of the reliability of the psychometric test, Cronbach's Alpha value is widely accepted as the main criterion used to determine the reliability of an instrument and it is satisfactory for a value greater than ,70 (Bland \& Altman, 1997). Cronbach's Alpha value $(\boldsymbol{\alpha}=, \mathbf{7 9 4})$ as the organization culture instrument in this study is much higher than the acceptable level at close to ,80 indicating that the questionnaire had a high reliability. Similarly, Cronbach's Alpha values measured for each sub-components were very close to ,80 (varying from ,784 to ,806). The Cronbach's Alpha Value for the four cultural traits are as follows: involvement trait $(, 628)$, consistency trait $(, 506)$, adaptability trait $(, 459)$ and mission trait $(, 631)$.

A validity analysis was used to determine whether the data was sufficient to measure the theoretical model and to determine the real-life equivalence of our theoretical approaches. Hence, we performed two tests to figure out the applicability of our data for structural explanation the results of which are seen in Table 3. The first points out the proportion of variance in our variables that might be caused by latent factors. The Kaiser-Meyer-Olkin Measure 
(KMO) of Sampling Adequacy Value implies that a variable is perfectly predicted by other variables. The value ranges from 0 to 1 , with 1 denoting the height of an error-free prediction, whereas values above ,80 are considered perfect (Buyukozturk, 2002) with the value of ,50 $(\mathrm{KMO} \leq, 50)$ is the lower limit (Field, 2000; 2005). The obtained KMO values for all of the models are $(O R G C U L T=, 756)$ and, respectively, for cultural traits $(I N V=, 737 ; C O N S=, 675$; $A D A P=, 640 ; M I S=, 700)$, they are satisfactory.

Table 3

Validity Analysis and Goodness of Fit Results for Organizational Culture Traits

\begin{tabular}{llllll}
\hline Cultural Traits & $\begin{array}{l}\text { KMO } \\
\text { Value }\end{array}$ & $\begin{array}{l}\text { Bartlett Test of } \\
\text { Sphericity } \\
\text { Value }\end{array}$ & Sig. & df & $\begin{array}{l}\text { Total } \\
\text { Variance } \\
\text { Explained }\end{array}$ \\
\hline Involvement &, 737 & 224,725 &, 000 & 36 & 49,146 \\
\hline Consistency &, 675 & 241,901 &, 000 & 36 & 49,982 \\
\hline Adaptability &, 640 & 171,519 &, 000 & 36 & 58,550 \\
\hline Mission &, 700 & 262,498 &, 000 & 36 & 50,907 \\
\hline TOTAL & $\mathbf{7 5 6}$ & 1715,214 &, 000 & 630 & $\mathbf{5 5 , 2 8 0}$ \\
\hline
\end{tabular}

Notes: Explained total variance values are singular values of the traits. The general value of the scale is given at the bottom.

The second test, the Bartlett Sphericity Test, however had results showing that chi-square values $\left(X^{2}{ }_{(630)}=1715,214 p<.01\right)$ are statistically significant for all variables and the overall scale. As per the validity / the reliability tests, our findings are in line with Yahyagil's (2004) study that claims that Denison's organizational culture scale is valid for Turkish firms.

Table 4

Meta-Analytic Correlations Among Indicants

\begin{tabular}{lllrrrrrrrrr}
\hline Categories & Mean & Std. Dev. & $\mathbf{1}$ & $\mathbf{2}$ & $\mathbf{3}$ & $\mathbf{4}$ & $\mathbf{5}$ & $\mathbf{6}$ & $\mathbf{7}$ & $\mathbf{8}$ & $\mathbf{9}$ \\
ROE (1) & 8,21 & 10,60 & 1.00 & & & & & & & & \\
ROA (2) & 17,37 & 71,69 & 0.33 & 1.00 & & & & & & & \\
DEBTEQTY (3) & 86,10 & 159,36 & 0.50 & 0.07 & 1.00 & & & & & & \\
SIZE (4) & 852,90 & 1436,25 & 0.33 & -0.04 & 0.62 & 1.00 & & & & & \\
AGE (5) & 45,22 & 20,14 & 0.24 & 0.19 & -0.04 & 0.25 & 1.00 & & & & \\
INV (6) & 3,66 &, 15 & -0.13 & -0.09 & -0.12 & -0.12 & -0.19 & 1.00 & & & \\
CONS (7) & 3,63 &, 16 & 0.06 & -0.10 & 0.27 & 0.24 & -0.19 & 0.44 & 1.00 & & \\
ADAP (8) & 3,63 &, 11 & -0.06 & -0.06 & -0.08 & -0.08 & 0.11 & 0.54 & 0.27 & 1.00 & \\
MIS (9) & 3,83 &, 14 & 0.06 & 0.12 & -0.008 & -0.03 & -0.05 & 0.38 & 0.14 & 0.33 & 1.00 \\
\hline N=
\end{tabular}

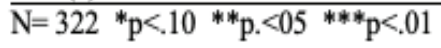

In addition to the reliability and validity analyses performed with CFA, we conducted a correlation analysis. With reference to Table 4, organizational culture variables, being overwhelmingly small, are not positively or negatively correlated with other financial variables or 
firm-specific variables with statistical significance at any level. While the differences were generally perfect as desired, on average, it can be clearly concluded from the table that the adaptability trait has the lowest intercorrelation value, having a negative sign with financial indicators, ROE $(-, 06)$, ROA $(-, 06)$ and DEBTEQTY $(-, 08)$ while the consistency trait has the highest $(, 06 ;-, 10 ;, 27$ in the same indicant order).

As previously emphasized in the methodology, our work consisted of a two-step regression model. Table 5 summarizes the steps taken to estimate the primary model with the OLS estimator under the same assumptions as for the cross-sectional data. As a result of numerous iterations, we determined that Model (5) can be tested as a basic model for the operating of corporate culture variables.

According to results displayed in Table 5, the ROA variable in model (1) gives statistically-significant results, implying that the profitability of equity increases when a rise occurs in the profitability of assets. As per the f-statistic value, the model is completely significant and the D-W statistic value shows that there is no auto-correlation between the variables. However, the Ramsey Reset Test $t$-value is statistically significant $(p<.01)$ and the coefficient has a positive sign. In this case, the Ho hypothesis, which states that the model has been established correctly, is rejected and the model must be strengthened by adding variables to the equation. Prior to the testing, and considering a missing variable in the model, the OVB Test shows that the $t$-value $(3,14)$ is statistically significant at the $1 \%$ level. The OVB test result implies another situation in which the hypothesis, which belongs to the DEBTEQTY variable, is the excluded (missing) variable in model (2), cannot be rejected and, therefore, we added the $\mathrm{DEBTEQTY}$ variable to model (2).

In model (2), by adding DEBTEQTY variable, the Ramsey Reset Test $t$-value (2.12) is a positive sign at a $5 \%$ significance level, and, likewise, the $H o$ hypothesis is still rejected. Hence, we decided to include the SIZE variable as a firm-specific variable, with the result implying that the model is still the missing variable.

Following a like path in models (3) and (4), the variable iterations regarding the Ramsey Reset Test and the OVB Test conveniently resulted in the forming of model (5). In accordance with model (5), Ramsey Reset Test result, which indicated that there is a functional error in the regression, signifies that the t-value (1.40) is statistically insignificant. The Ho hypothesis cannot be rejected at this time, and the result implies that the regression model is free from functional error.

When all the models were taken into consideration, the $R O A$ variable gave consistent statistically results in terms of explaining it. As to the other explanatory financial indicator, the $D E B T E Q T Y$ variable produced statistically significant and meaningful results, except for the regression model (3). The SIZE variable accordingly produced a statistically insignificant 
result just in model (3) in line with DEBTEQTY. Prior to the firm-specific variable, included in the regression model (4) and model (5), the $S I Z E^{2}$ variable inherently had a negative coefficient sign within the expectations, making it is statistically significant, while the $A G E$ variable did not statistically yield any significant result. However, the $A G E$ variable was kept in the regression model due to being a component of the interaction terms.

Table 5

Results for Basic Regression Model

\begin{tabular}{|c|c|c|c|c|c|}
\hline \multicolumn{6}{|c|}{$\begin{array}{c}\text { Dependent Variable } \\
\text { ROE (Return On Equity) }\end{array}$} \\
\hline Model No & (1) & (2) & (3) & (4) & (5) \\
\hline Explanatory Variables & \multicolumn{5}{|c|}{ Coefficient values of variables / $t$-statistic values } \\
\hline Drift Term $\left(a_{i t}\right)$ & $\begin{array}{l}7,363 \\
(3,85)^{\star \star \star}\end{array}$ & $\begin{array}{l}4,693 \\
(2,44)^{\star \star}\end{array}$ & $\begin{array}{l}4,475 \\
(2,10)^{\star \star}\end{array}$ & $\begin{array}{l}0,792 \\
(0,35)\end{array}$ & $\begin{array}{l}-2,703 \\
(-0,73)\end{array}$ \\
\hline$R O A$ & $\begin{array}{l}0,049 \\
(6,72)^{\star \star \star}\end{array}$ & $\begin{array}{l}0,043 \\
(5,39)^{\star *}\end{array}$ & $\begin{array}{l}0,044 \\
(4,92)^{\star \star \star *}\end{array}$ & $\begin{array}{l}0,041 \\
(5,62)^{\star * \star}\end{array}$ & $\begin{array}{l}0,035 \\
(4,16)^{\star \star \star}\end{array}$ \\
\hline$D E B T E Q T Y$ & & $\begin{array}{l}0,032 \\
(2,34)^{\star *}\end{array}$ & $\begin{array}{l}0,029 \\
(1,44)\end{array}$ & $\begin{array}{l}0,032 \\
(2,24)^{\star \star}\end{array}$ & $\begin{array}{l}0,036 \\
(2,67)^{\star \star}\end{array}$ \\
\hline$S I Z E$ & & & $\begin{array}{l}0,0006 \\
(0,26)\end{array}$ & $\begin{array}{l}0,009 \\
(3,85)^{\star \star \star \star}\end{array}$ & $\begin{array}{l}0,008 \\
(3,25)^{\star * \star}\end{array}$ \\
\hline$S I Z E^{2}$ & & & & $\begin{array}{l}-1,29 \mathrm{E}-06 \\
(-5,11)^{\star * *}\end{array}$ & $\begin{array}{l}-1,23 E-06 \\
(-4,68)^{\star * *}\end{array}$ \\
\hline$A G E$ & & & & & $\begin{array}{l}0,086 \\
(1,21)\end{array}$ \\
\hline Observation & 31 & 31 & 31 & 31 & 31 \\
\hline$R^{2}$ & 0,109 & 0,341 & 0,344 & 0,548 & 0,569 \\
\hline Adjusted $R^{2}$ & 0,078 & 0,294 & 0,272 & 0,478 & 0,483 \\
\hline$f$-test value & $3,56^{*}$ & $7,25^{* * * *}$ & $4,73^{* * * *}$ & $7,88^{* * * *}$ & $6,62^{* * * *}$ \\
\hline D-W statistic value & 2,35 & 2,34 & 2,33 & 2,29 & 2,39 \\
\hline OVB Test ( $t$-value) & - & $3,14^{* * * *}$ & 0,37 & $3,42^{* * * *}$ & 1,12 \\
\hline Ramsey's Reset $t$-value & $5,36^{* * * *}$ & $2,12^{* *}$ & $4,84 * * *$ & 1,61 & 1,40 \\
\hline
\end{tabular}

When the structural strength of the established models was examined, the $f$-statistical test values were significant at the 1\% level in models (2), (3), (4) and (5) and all of these models were statistically significant. For the $R^{2}$ and adjusted $R^{2}$ values that demonstrate the description power of the models, they increased in terms of the four models (ranging from , 109 to ,548), arriving at the last regression model (5) with a value (,569). In addition, the $D$ - $W$ test values displayed no auto-correlation between the predictor employed in all five models.

As a result, it may finally be stated that the variables - employed in order to illuminate the effect of $\mathrm{C} / \mathrm{P}$ in accordance with the main purpose of the study and to purge this effect of potential randomness - generated consistent and stable results in line with our expectations. Therefore model (5) is determined as the basic regression model to test the $\mathrm{C} / \mathrm{P}$ link.

\section{Main Results For Hypothesized Effects}

In the following section, we proceed to the tests that reveal the hypothesized effects of the main research questions and present our estimation results for the effect of $\mathrm{C} / \mathrm{P}$. The main and 
relative findings of the research are included in this section.

Subsequent to extending model (5) and regressing the return on equity against auxiliary financial predictors and firm-specific variables, we ran a ten-stage regression by positing cultural variables to the basic model to test the main hypotheses of the study. In these regressions, we tested each cultural variable twice both on its own and in interaction terms.

Table 6 summarizes our ten-step regression results. It's visible that all regression models clarify a significant portion of the observed variances in the dependent variables with $R^{2}$ 's extending from ,569 to ,607 while the $f$-statistic values range from 4,38 to 6,18 , exhibiting that all the models are in the statistically $(p<.01)$ significant level. In addition, Durbin-Watson's statistical values, ranging from 2,30 to 2,40 , indicate that there is no auto-correlation between regressors. All the diagnostic tests, such as Ramsey's Reset, $f$-statistical test or the OVB Test on the structural stability of the models show that our model does not carry any functional forms, auto-correlation heteroscedasticity problems.

Next, as to relative effects, the return on asset indicator was shown to be of the most consistent statistical significance $(p<.01)$ in explaining the return on equity indicant in all models, while its coefficient sign evidently turned negative in model (15). These results are in line with our expectations and it can clearly be concluded from the results that one-unit growth in return on asset causes an increase in return on equity at various levels except for model (15). Also within expectations, the debt to equity ratio is another stable financial predictor performing a statistical significance in all regression models, explaining the dependent variables. Moreover, the $D E B T E Q T Y$ variable, having a constant positive sign, was generally at the $(p<.01)$ significance level, while it was at the $(p<.05)$ significant level for model (14) and (15).

The results imply that when an increase occurs in the debt to equity ratio, it results in an increase in return on equity. However these results should be handled with care due to the financial standpoints stemming from theoretically diversified remarks about capital structure's effect on profitability. We recommend that this finding should not be dealt with independently from other studies examining the interaction between capital cost and firm profitability and, accordingly, from any financial approaches such as how leverage influences profitability.

Proceeding with the relative effects of firm-specific variables, the coefficient sign of the firm size variable was positive and all values were statistically significant at the $(p<.01)$ level. Firm size is apparent in a linear form and a positive interaction with return on equity and this finding crystalizes the relationship between number of employees and profitability in the same direction. However the square of the firm size had negative signs and the values were all significant at the $(p<.01)$ level, as expected. But the other firm specific variable, age, was statistically insignificant in all models although having positive or negative signs. 


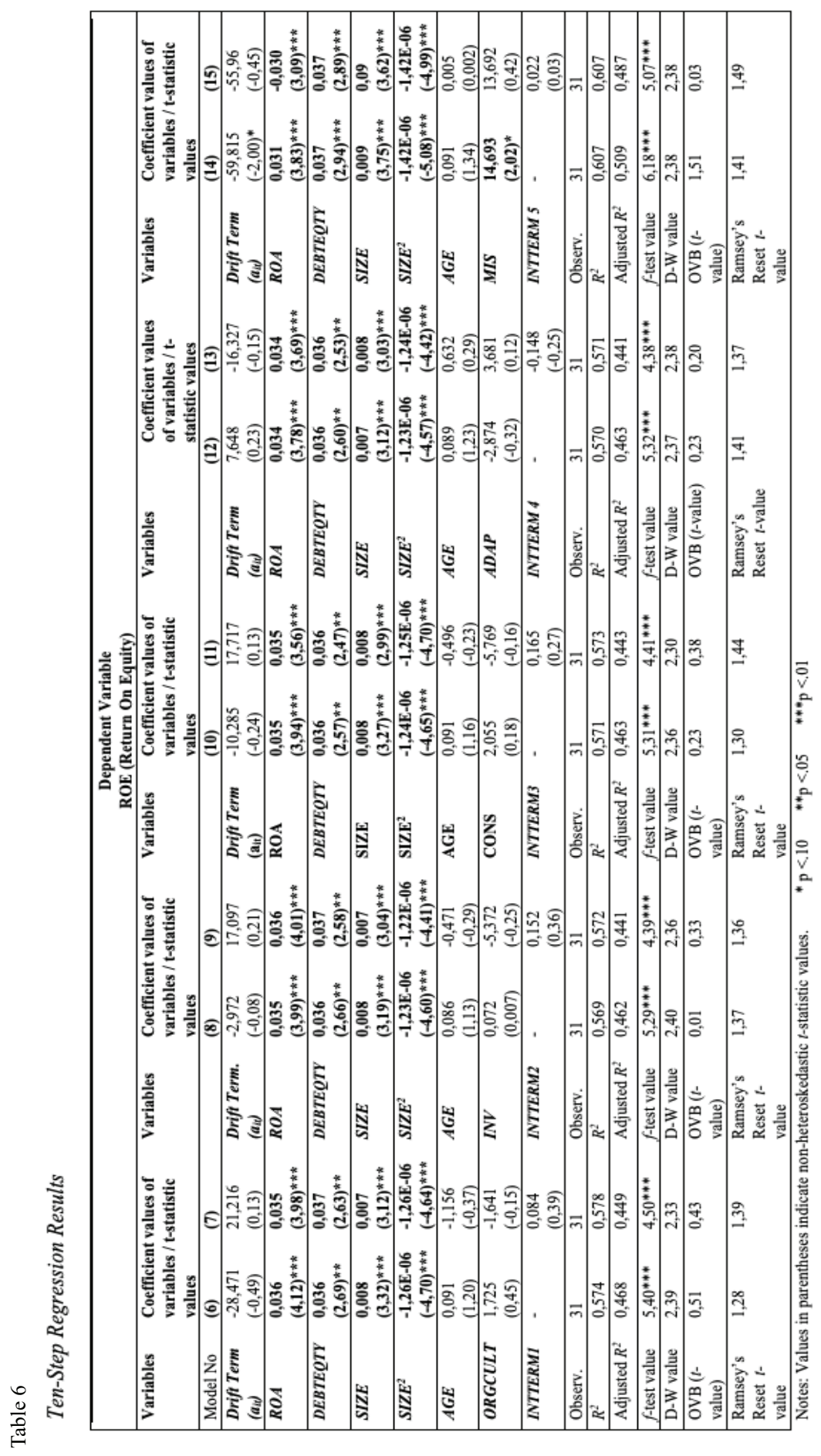


As to the main effects, foremost considering model (6), the composite organizational culture indicator, ORGCULT $\left(\beta_{\mathrm{i}}=1,72\right)$, is revealed to have a positive impact over return on equity. But this effect does not contain any statistical significance. By the way, the first interaction term (INTTERM1) seems to not have made any remarkable contribution to the model while clearly displayed in model (7). With the inclusion of INTTERM1 $\left(\beta_{\mathrm{i}}=0,08\right)$, just the sign of the coefficients which belong to ORGCULT $\left(\beta_{\mathrm{i}}=-1,64\right)$ and $A G E\left(\beta_{\mathrm{i}}=-1,15\right)$ variables have turned into negative. Eventually, while models (6) and (7) are completely significant at $(p<.01)$ level, by the sum of cultural traits the organizational culture variable is statistically insignificant to explain the dependent variable, $R O E$. The hypothesized effect indicating that the organizational culture positively affects firm financial performance is not confirmed in our study and therefore Hypothesis-1 $\left(H_{1}\right)$ is rejected.

To explicate major effects with the four cultural traits, we primarily appended the involvement trait to model (8) and the results show that the $I N V$ predictor $\left(\beta_{\mathrm{i}}=0,07\right)$ had no statistical significance explaining return on equity, although it had a positive sign. As displayed in model (9), the second interaction term, (INTTERM2), formed to reveal the joint effect of the involvement score and the firm age, seems not to have had any meaningful impact on the model similar to the ORGCULT variable. When INTTERM2 $\left(\beta_{\mathrm{i}}=0,15\right)$ is inserted into the regression in model (9), just the sign of the coefficients that belong to $\operatorname{INV}\left(\beta_{\mathrm{i}}=-5,37\right)$ and $A G E\left(\beta_{\mathrm{i}}=-0,47\right)$ variables turned into a negative. Regarding models (8) and(9), the $I N V$ and INTTERM2 variables were statistically insignificant to explain the dependent variable $(R O E)$, although the two models were completely significant at the $(p<.01)$ level. The hypothesized effect indicating that the involvement trait positively affects firm financial performance is not confirmed in our study and, therefore, Hypothesis-2 $\left(\mathrm{H}_{2}\right)$ is rejected.

Similarly, considering the effects of other cultural traits, the regression results show that neither the CONS nor the $A D A P$ predictor reflected any statistical significance in models $\left(10 ; 11 ; 12\right.$ and13), although $C O N S\left(\beta_{\mathrm{i}}=2,05\right)$ had a positive sign in model (10) and $A D A P$ $\left(\beta_{\mathrm{i}}=-2,87\right)$ had a negative sign in model $(12)$. When the results were assessed with regard to interaction terms posited to model $(11 ; 13), C O N S\left(\beta_{\mathrm{i}}=-5,76\right)$ turned to negative while INTTERM3 $\left(\beta_{\mathrm{i}}=0,16\right)$ had a positive sign in model $(11)$. Inversely, $A D A P\left(\beta_{\mathrm{i}}=-2,87\right)$ had a negative sign in model $(12)$ and $\left(\beta_{\mathrm{i}}=3,68\right)$ turned into positive while INTTERM4 $\left(\beta_{\mathrm{i}}=-0,14\right)$ appeared with a negative sign in model (13). It is quite comprehensible that when the interaction terms get involved in a regression, the coefficient signs of the two components, each cultural trait and firm age, prominently switched to the opposite sign due to their nature. As to the hypothesized effect indicating that the involvement trait and also the adaptability trait positively affected return on equity, they are confirmed in our study and, therefore, Hypothesis-3 $\left(\mathrm{H}_{3}\right)$ and Hypothesis-4 $\left(\mathrm{H}_{4}\right)$ were rejected.

Next, complying with the same analysis design, estimation results that belong to the mission trait distinctly differ from other cultural characteristics. Possessing the maximal value of the beta coefficient among other traits, MIS $\left(\beta_{\mathrm{i}}=14,69\right)$ also had a positive sign. 
Moreover, this sign was significant at the $(p<.10)$ level as clearly visible in model (14). But INTTERM5 $\left(\beta_{\mathrm{i}}=0,02\right)$ formed to indicate the joint-effect of the mission score and firm age had a low beta value and repeatedly displayed insignificant results in model (15), although having a positive sign. Regarding models (14) and (15), the MIS variable consequently showed a meaningful effect to explain return on equity, whereas the INTTERM5 variable was statistically insignificant although both were completely significant at the $(p<.01)$ level. The hypothesized effect indicating that the involvement trait positively affects a firm financial performance was confirmed at the $(p<.10)$ level in our study and, therefore, Hypothesis-5 $\left(\mathrm{H}_{5}\right)$ is accepted.

Consequently, among the 15 regression models of which five were formed to ensure consistent results for testing cultural traits, only the mission trait was statistically significant at the $(p<.10)$ level while the organizational culture itself, including the involvement, consistency and adaptability traits, did not show any statistical significance. Five cases flavored by algebraic multiplication, namely as interaction terms, did not leave any respectable impact on the models, and the explained variance for the dependent variables did not deviate much between the non-attached and attached manner. Finally, Hypothesis (5) is accepted while Hypotheses $(1 ; 2 ; 3 ; 4)$ are rejected. The discussion and conclusion section below clarifies the implications of our research findings.

\section{Discussion and Implications}

Our research differs from other $\mathrm{C} / \mathrm{P}$ studies that have employed objective and subjective financial criteria together. We have solely employed the most critical indicator of bottomline performance, ROE, as the dependent variable. With reference to the DOCM, we also analyzed the overall organisational culture itself as represented by the combination of four characteristics with reference to "hard" financial performance criteria.

The findings of this study clearly show that only the mission trait has a positive effect on the financial indicator while the other cultural traits in the DOCM exhibit no meaningful effect. Although the study had hypothesized that cultural characteristics and the organizational culture itself, have a positive effect on firm performance, the effect could not accurately be confirmed in the research just apart from one trait. Hence, our findings signify that $H_{1}$ as the main hypothesis of the study and $\mathrm{H}_{2}, \mathrm{H}_{3}$ and $\mathrm{H}_{4}$ that stand for cultural traits are rejected, while only $\mathrm{H}_{5}$ is accepted.

First, as to the findings related to involvement trait, the findings are supporting the results of the past works by Kotter \& Heskett (1992) in the U.S., Garmendia (2004) in Spain, Davidson et al. (2007) in South Africa. Our findings also back the findings of the works by Eren, Alpkan \& Ergun (2003) and Y1lmaz \& Ergun (2008) conducted in Turkey. 
The findings belonging to the involvement trait have profound theoretical-practical implications and deserve further explanation. According to evidence, there may naturally be a strong belief among employees that organizations own their participatory processes and these processes are in line with business objectives. Although this is widely considered and shared among employees and the perception is reflected in the responses of the participants, the mood of the organization seems to not make any contribution to success. We clearly attribute the participatory work environment to the organization, developed on the basis of both members and departments, knowing that hidden disagreements or conflicts might be caused inside by paying high attention to and firmly adhering to their own ideas. In this manner, the concealed disagreements in the organization create an obstacle for desired business performance. Next, individual and organizational goals directed to employees may be incompatible with the involvement culture and might be pushing the members to be self-centered. Thirdly, we note that cultural forms are close together. In our opinion, the conceptual similarity between the involvement culture and strong culture form, makes it difficult to discern any difference between the two. In this way, our extraction can be interpreted in parallel to Kotter \& Heskett (1992)'s study hypothesizing that the firms with strong culture had superior financial outcomes.

As to the consistency trait, The findings related to the consistency trait are similar to the findings of the studies by Kotter \& Heskett (1992) in the U.S., Fey \& Denison (2003) in Russia, Eren et al. (2003) in Turkey, Garmendia (2004) in Spain, Davidson et al. (2007) in South Africa and Okoro (2010) in Nigeria context while in dissimilar to the findings of the studies by Denison \& Mishra $(1985 ; 1995)$ in the U.S., Gordon \& Di Tomaso (1992) in the U.S., Schein (1992), Sorensen (2002) in the U.S., Nazir \& Lone (2008) in India, Zakari et al. (2013) in Ghana and Glaser (2014) in the U.S. context.

Findings on the consistency trait imply that the integrative mood felt by combining core values with the agreement and coordination in the organization hardly ever contribute to business performance, even if they seem to increase employee's corporate loyalty and cooperation related to their activities. Among the possible reasons for this implication, it can be argued that attitudes and behaviors based upon core values are not congruent with the firms' economic goals. Accordingly, this view contains an intrinsic contradiction and it can be assumed that activities carried out by agreement and coordination prevent employees from unifying around organizational targets. But as stated by Yllmaz and Ergun (2008) enterprises with a strong culture where internal integration is high, may be deficient in adapting to the external environment and inadequate in meeting the demands of a cultural market lacking flexibility. It is worth considering and may also be valid for chemical enterprises that operate within the intense and rapid-changing competition environment. Thus, the business environment can be a decisive factor in a firm's economic performance.

Our findings related to the adaptability trait are in a different direction than those of the research by Denison \& Mishra $(1989,1995)$ in the U.S., Gordon \& Di Tomaso $(1992)$ in the 
U.S., Fey \& Denison (2000) in Russia, Eren et al. (2003) in Turkey, Nazir \& Lone (2008) in India, Hartnell et al. (2011) in the U.S., Fekete \& Böcksei (2011) in Hungary while they are in line with the studies of Davidson (2003) in South Africa, Yilmaz \& Ergun (2008) in Turkey, Han (2012) in South Korea, Yeşil \& Kaya (2013) in Turkey, Ghanavati (2014) in Iran, Glaser (2014) in the U.S. and Pinho et al. (2014) in the Portuguese context.

There are several reasons why the adaptability trait is insufficient to explain ROE. First of all, it can be postulated that chemical enterprises in intense competition fail to predict the market and adapt their culture to environmental change. Besides, it may be stated that an external focus has a different impact than the one on firm performance. Because an external focus gives flexibility and quick movement to a firm, it differs from the internal integration dimension that involves more cumbersome and heavier change. Therefore, a sensitive environmentally-focused culture can be expected to become a faster determinant of market share and profitability. In addition, the internal functions of a business that aim to improve its external focus can interfere with change. In a sense, the system of internal norms and beliefs may be incompetent to perceive, understand and convert the demands from the external environment into targeted financial results. Hence, the unwieldiness and slowness of the existing internal integration (or strong culture) may prevail within an organization, impeding the development of a flexible culture in terms of making changes to the environment.

Finally, one of the most obvious findings in the study is that the mission trait has a statistically significant and positive effect on return on equity $(p<.10)$, although other cultural traits give statistically insignificant results on financial indicators. This might be interpreted as perhaps the most intriguing finding in the study. Having the maximum dimensional score $(3,81)$ among others, the findings belonging to the mission trait are in line with expectations.

Our findings provide empirical evidence that a clear vision of long-term goals adopted with an organizational orientation and a business vision would back the achievement of the desired financial performance. Because in a mission-dominated culture, the whole organization focuses on long-term goals and does not divert its direction with short-term fluctuations. Subject to the findings of the study, it is possible to emphasize that the business objectives clearly defined and shared with the employees, the strategic guidance made to the employees in line with these objectives and the sharing business vision with the employees by adopting them can play a critical role in the achievement of their business success. However, our findings suggest that long-term financial success can be achieved by defining long-term goals and organizational unification around the vision while not suggesting that other cultural traits should be overlooked.

The findings related to the mission trait support the results of the past work of Denison \& Mishra (1989; 1995) in the US, Fisher (1997) in the US, Nazir \& Lone (2008) in India, Okoro (2010) in Nigeria, Zakari et al. (2013) in Ghana, Olughor (2014) in Nigeria and Glaser (2014) 
in US, while not supporting the work of Davidson (2003) in South Africa. Our findings also back those of Eren et al. (2003) and Yilmaz \& Ergun (2008)'s research conducted in Turkey.

In sum, with the terms of the four cultural characteristics of Denison's Theory, it is quite noticeable that findings of the previous $\mathrm{C} / \mathrm{P}$ works which were conducted in Turkey and different countries revolved around the mission trait. Our findings are widely in line with the results of other studies, indicating that the mission culture is the central cultural term in assuring business success. As such, the present study implies one important lesson for practitioners who are concerned for the success of their organizations, a mission-dominated culture to be developed around a strategic direction, common goals-objectives and a long-term vision, all critical to the improvement of business financial performance.

\section{Limitations and Directions For Future Research}

Some limitations should be taken into consideration when evaluating the findings of our study. First, a relatively small number of firms is included in the analysis, but this should not be presumed as a negative factor thanks to the adequate sample size. However, the authors of the present study strongly recommend that further studies, through increasing the number of enterprises, would augment more reliable results.

Second, we conducted research using the five-year financial data of the selected enterprises. Other factors naturally have been influential on these firms' financials. Especially in developing countries, such as Turkey, there is strong possibility that the reflection of structural and fiscal fragilities in the economy may leave a mark on companies' financials. In this sense, we signal the difficulty to determine the precise contribution of intangible assets, such as the corporate culture that cannot be located in the tables of financial statements.

Third, we had to contend with a lack of information about internal processes and supportive observations inside the plants apart from the survey data limits on the evaluation of our findings. This restricted our observational evaluation as to whether there was an institutional awareness of the concept and importance of corporate culture in the enterprises constituting the sample of the study. To us, the relationship still remains hypothetical while some optimistic research exists in the literature. We underscore that this hypothetical relationship may be revealed more clearly and consistently with the help of better corporate culture and financial performance data, which will be collected over a longer period of time, along with supporting internal observations in subsequent work.

The fourth limitation was our decision to employ a hard (objective) performance indicator to estimate the five-year average that did not allow us to operate a multivariate selection for the dependent variables. However, some previous work (e.g. Denison and Mishra, 1989; Denison 
and Mishra, 1995; Fey and Denison, 2000; Hartnell et al. 2011) has proved that culture is likely to have a significant impact on soft (subjective) criteria based on perceptions of growth, customer satisfaction, product-service quality, etc. In this study, corporate culture has not been evaluated with a measurement of perceptions due to selecting a hard financial indicant. This may have created a congeniality problem between the financial indicant and the cultural criteria.

The fifth should be evaluated together with the second as it is related to the impact of the firm's managerial decisions in the areas of financing and investments. Thus, investment and financing decisions such as working capital, dividend policy and capital structure may leave a dense mark on the financial statements and show a possible hypothesis impact of the culture on performance that might have been overshadowed by managerial financial decisions. Thus, the matter of how top executives perceive culture and how it maintains influential domination over managerial financing and investment decisions that affect financial statements is worth investigating. Future research could investigate the factors in detail for approachment of top executives that prevail over the $\mathrm{C} / \mathrm{P}$ connection.

Peer-review: Externally peer-reviewed.

Author Contributions: Conception/Design of study: A.B., H.R.A.; Data Acquisition: A.B., H.R.A.; Data Analysis/Interpretation: A.B., H.R.A.; Drafting Manuscript: A.B., H.R.A.; Critical Revision of Manuscript: A.B.; Final Approval and Accountability: A.B., H.R.A.

Conflict of Interest: The authors have no conflict of interest to declare.

Grant Support: Afyon Kocatepe University, Scientific Research Projects Commission, Project Number: 15.SOSBIL.02.

\section{References}

Bezrukova, K., Thatcher, S., Jehn, K. A., \& Spell, C. S. 2012. The effects of alignments: Examining group faultlines, organizational cultures and performance. Journal of Applied Psychology, 97, 77-92.

Bland, J. M., \& Altman, D. G. 1997. Statistics notes: Cronbach's alpha. British Medical Journal, 314, 572.

Boyce, A. S., Nieminen, L. R., Gillespie, M. A., Ryan, A. M., \& Denison, D. R. 2015. Which comes first, organizational culture or performance? A longitudinal study of causal priority with automobile dealerships. Journal of Organizational Behavior, 36,339-359.

Buyukozturk, Ş. 2002. Faktör analizi: Temel kavramlar ve ölçek geliştirmede kullanımı. Kuram ve Uygulamada Eğitim Yönetimi / Factor analysis: Basic concepts and its use in scale development. Educational Administration in Theory and Practice 32,470-483.

Cakir, H. M., \& Kucukkaplan, İ. (2012). İşletme sermayesi unsurlarının firma değeri ve karlılığı üzerindeki etkisinin IMKB'de işlem gören üretim firmalarında 2000-2009 dönemi için analizi. Muhasebe ve Finansman Dergisi / Analyzing effects of working capital component on profitability and valuation at manufacturing firm in ISE for 2000-2009 Period, Journal of Accounting \& Finance, 1, 69-86.

Christensen, E. W., \& Gordon, G. G. 1999. An exploration of industry, culture and revenue growth. Organization Studies, 20, 397-422.

Davidson, G. M. 2003. The Relationship Between Organisational Culture and Financial Performance in a South African Investment Bank. Unpublished Master of Commerce Dissertation, University of South Africa. 
Davidson, G., Coetzee, M., \& Visser, D. 2007. Organisational culture and financial performance in a South African investment bank. SA Journal of Industrial Psychology, 33, 38-48.

Denison, D. R., \& Mishra, A. K. 1989. Organizational culture and organizational effectiveness: A theory and some preliminary empirical evidence. In Academy of Management Proceedings, 1, 168-172.

Denison, D. R., \& Mishra, A. K. 1995. Toward a theory of organizational culture and effectiveness. Organization Science, 6, 204-223.

Denison, D. R. 1990. Corporate Culture and Organizational Effectiveness. New Jersey: John Wiley and Sons.

Denison, D. R., \& Mishra, A. K. 1995. Toward a theory of organizational culture and effectiveness. Organization Science, 6, 204-223.

Denison, D. R., \& Neale, W. 1996. Denison organizational culture survey. Ann Arbor, MI: Aviat.

Denison, D. R., Haaland, R., \& Goelzer, S. P. 2003a. Corporate culture and organizational effectiveness: Is there a similar pattern around the World? Advances in Global Leadership, 3, 205-227.

Denison, D. R., Haaland, R., \& Goelzer, S. P. 2003b. Corporate culture and organizational effectiveness: Is Asia different from the rest of the World? Organizational Dynamics, 33, 98-109.

Denison, D., Nieminen, L., \& Kotrba, L. 2014. Diagnosing organizational cultures: A conceptual and empirical review of culture effectiveness surveys. European Journal of Work and Organizational Psycho$\log y, 23,145-161$.

Eren, E., Alpkan, L., \& Ergun, E. 2003. Kültürel boyutlar olarak işletmelerde içsel bütünleşme ve dişsal odaklanma düzeylerinin performansa etkileri. Doğuş Üniversitesi Dergisi / The Effects on the managerial performance of the levels of internal integration and external orientations cultural dimensions within the firms, Journal of Dogus University, 4, 55-70.

Fekete, H., \& Bocskei, E. 2011. Cultural waves in company performance. Research Journal of Economics, Business and ICT, 3.

Fey, C.F., \& Denison, D.N. 2000. Organization Culture And Effectiveness: The Case of Foreign Firms in Russia and Sweden. Working Paper Services in Business Administration, (4).

Fey, C. F., \& Denison, D. R. 2003. Organizational culture and effectiveness: can American theory be applied in Russia? Organization Science, 14, 686-706.

Field, A. 2000. Discovering Statistics Using SPSS For Windows. Thousand Oaks. London. Sage Publications.

Field, A. 2005. Discovering Statistics Using SPSS . Thousand Oaks, CA, US.

Fisher, C. J. 1997. Corporate Culture and Perceived Business Performance: A Study of the Relationship Between the Culture of An Organization and Perceptions of Its Financial and Qualitative Performance. Unpublished PhD Dissertation, California School of Professional Psychology, Los Angeles.

Garmendia, J. A. 2004. The impact of corporate culture on company performance. Current Sociology, 52, 1021-1038.

Ghanavati, M. 2014. The effect of corporate culture and market orientation on Iranian industrial SMEs' performance. Iranian Journal of Management Studies, 7, 413-436.

Glaser, B. J. 2014. Organizational Culture and Financial Performance and the Moderating Effect of Organizational Age. Unpublished PhD Dissertation, Walden University, Minneapolis.

Gordon, G. G., \& Di Tomaso, N. 1992. Predicting corporate performance from organizational culture. Journal of Management Studies, 29, 783-798. 
Han, H. 2012. The relationship among corporate culture, strategic orientation and financial performance. Cornell Hospitality Quarterly, 53, 207-219.

Hartnell, C. A., Ou, A. Y., \& Kinicki, A. 2011. Organizational culture and organizational effectiveness: A meta-analytic investigation of the competing values framework's theoretical suppositions. Journal of Applied Psychology, 96, 677.

Hofstede, G., \& Peterson, M. F. 2000. Culture: National values and organizational practices. Handbook of Organizational Culture and Climate, 3, 401-416.

Hofstede, G. 2004. Cultures and Organizations:Software of the Mind. New York: McGraw Hill.

Horváth, R., \& Spirollari, P. 2012. Do the board of directors' characteristics influence firm's performance? The US evidence. Prague Economic Papers, 4, 470-486.

John, A. O., \& Adebayo, O. 2013. Effect of firm size on profitability: Evidence from Nigerian manufacturing sector. Prime Journal of Business Administration and Management, 3, 1171-1175.

Kaen, F. R., \& Baumann, H. D. 2003. Firm size, employees and profitability in US manufacturing industries. Social Science Research Network, 2, 746-751.

Karaca-Mandic, P., Norton, E. C., \& Dowd, B. 2012. Interaction Terms in Nonlinear Models. Health Services Research, 47, 255-274.

Koerniadi, H., \& Tourani-Rad, A. 2012. Does Board Independence Matter? Evidence From New Zealand. Australasian Accounting Business and Finance Journal, 6, 3-18.

Kotter, J. P., \& Heskett, J. L. 1992. Corporate Culture and Performance.New York:Free Press.

Lewin, K. 1951. Field Theory In Social Science: Selected Theoretical Papers. (edited by Dorwin Cartwright.). Tavistok Publications Ltd.

Makori, D. M., \& Jagongo, A. O. 2013. Working capital management and firm profitability: Empirical evidence from manufacturing and construction firms listed on Nairobi securities exchange, Kenya. International Journal of Accounting and Taxation, 1, 1-14.

Nazir, N. A., \& Lone, M. A. 2008. Validation of Denison's model of organisational culture and effectiveness in the Indian context. Vision, 12, 49-58.

Okoro, H. M. 2010. The Relationship Between Organizational Culture and Performance: Merger in the Nigerian Banking Industry. Unpublished PhD Dissertation, University of Phoenix.

Olughor, R.J. 2014. Corporate entrepreneurship and employee retention strategies in Nigerian telecommunication industry. European Journal of Business and Social Sciences, 3, 9-23.

Ongore, V. O., \& Kusa, G. B. 2013. Determinants of financial performance ofcommercial banks in Kenya. International Journal of Economics and Financial Issues, 3, 237-252.

Petty, M. M., Beadles, N. A., Lowery, C. M., Chapman, D. F., \& Connell, D. W. 1995. 'Relationships between organizational culture and organizational performance'. Psychological Reports, 76, 483-492. DOI: 10.2466/pr0.1995.76.2.483

Pinho, C., Rodrigues, J.P., \& Dibb, S.A. 2014. The Role of corporate culture, market orientation and organisational commitment in organisational performance: The case of non-profit organisations. Journal of Management Development, 33, 374-398.

Schein, E. H. 1985. Organizational Culture and Leadership: A Dynamic View. San Francisco: John Wiley and Sons.

Sørensen, J. B. 2002. The strength of corporate culture and the reliability of firm performance. Administrative Science Quarterly, 47, 70-91. 
Yahyagil, M. Y. 2004. Denison örgüt kültürü ölçme aracının geçerlik ve güvenirlik çalışması: ampirik bir uygulama. İstanbul Üniversitesi Işsletme İktisadı Enstitüsü Yönetim Dergisi / An empirical study on the validity and reliability tests of Denison Organizational Culture Questionnaire, Istanbul University Institute of Business Economics Management Journal, 47, 53-76.

Yeşil, S., \& Kaya, A. 2013. The effect of organizational culture on firm financial performance: evidence from a developing country. Procedia-Social and Behavioral Sciences, 81, 428-437.

Y1lmaz, C., \& Ergun, E. 2008. Organizational culture and firm effectiveness: An examination of relative effects of culture traits and the balanced culture hypothesis in an emerging economy. Journal of World Business, 43, 290-306.

Zakari, M., Poku, K., \& Owusu-Ansah, W. 2013. Organizational culture and organisational performance: Empirical evidence from the banking industry in Ghana. International Journal of Business, Humanities and Technology, 3, 95-107.

Zheng, W., Qu, Q., \& Yang, B. 2009. Toward a theory of organizational cultural evolution. Human Resource Development Review, 8, 151-173. 